Historic, Archive Document

Do not assume content reflects current scientific knowledge, policies, or practices. 



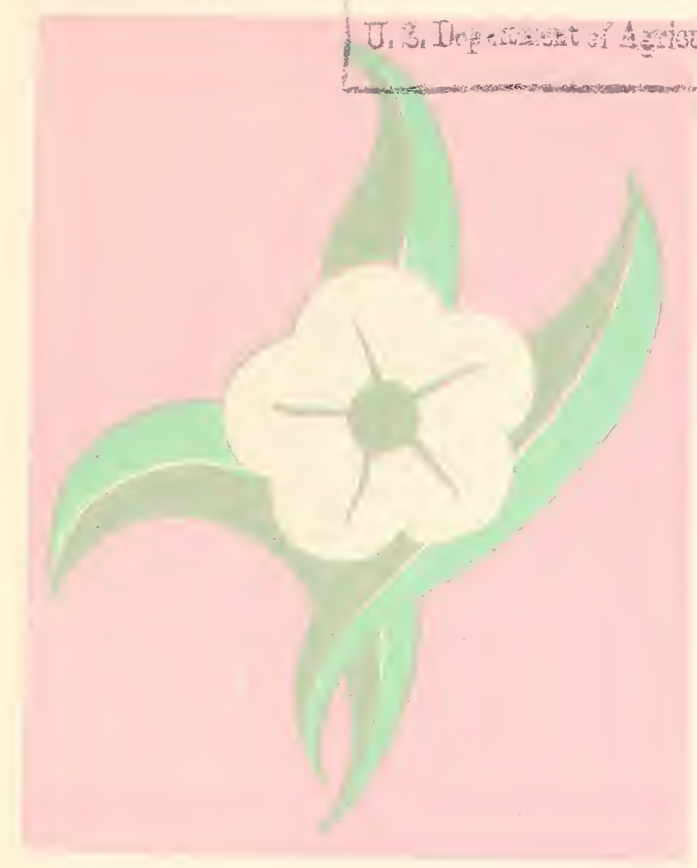

\section{CATALOG FOR 1930}

Glardy and Atnnual
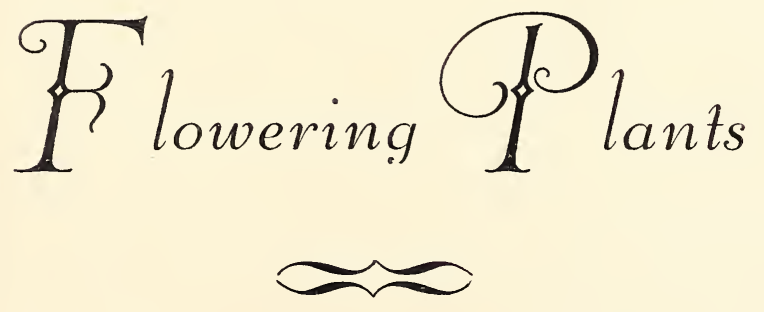

Berkins Brothers

Morth $\int_{\text {aint }} P_{\text {aul, }}$ Minnesota

Vegetable Seed Trials

D. N. Shoemaker

MAR 101930 



\section{CATALOG FOR 1930}
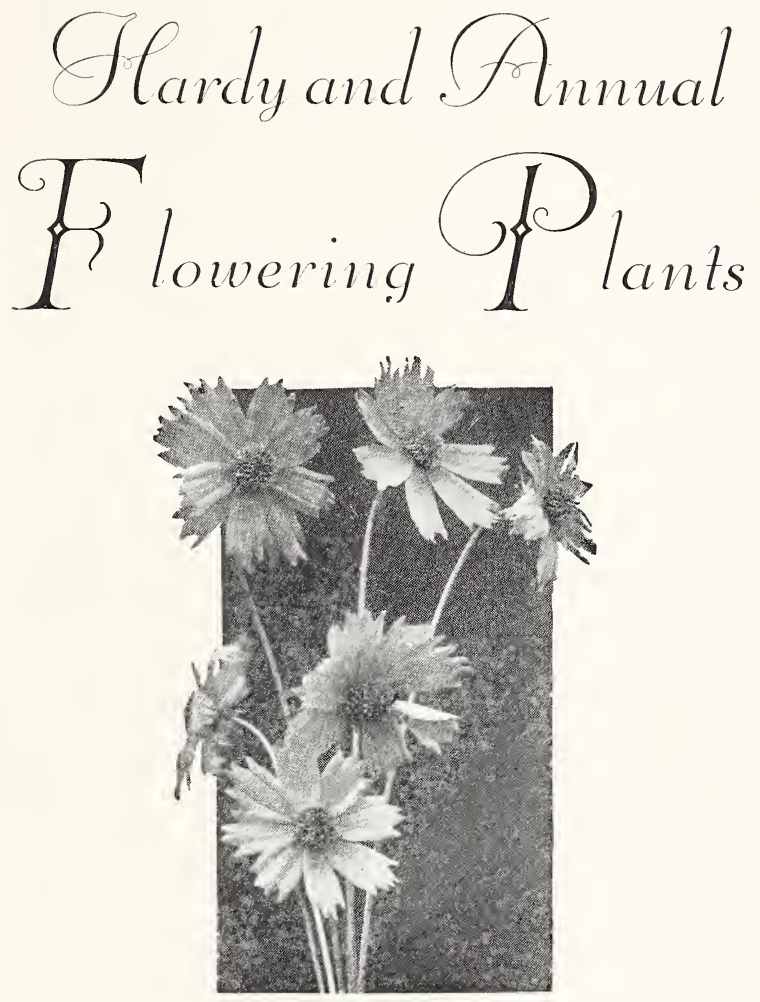

COREOPSIS

\section{Perkins Brothers}

Morth $\int_{\text {aint }} \mathcal{P}_{\text {aul }}$ Minnesota GARDENS STILLWATER ROAD, RAMSEY COUNTY, MINNESOTA TELEPHONE TOWER 68945 


\section{Greetings}

Since some of you may not be able to come to our nursery and meet us personally we are sending all our garden friends this little catalog, with the best of wishes for a successful garden the coming season. We all welcome the return of spring, and while we are waiting for the ground to warm up, we like to read the catalogs that come to us. We have endeavored to make this ittle booklet interesting and we hope you will find something of value to you in it.

Besides the prospect of spring we have the additional pleasure of anticipating a visit from many of you. These personal meetings enable us to give you better service because we can get acquainted with your ideas about gardens.

At this time we wish to express our appreciation of the business given us by our customers, and their kindness in telling their friends and neighbors about our plants.

We believe we can render you a better service than has been possible before. Besides adding a number of varieties of perennials and annuals to our lists, we will have many annuals in separate colors. This makes it easier for you to develop color schemes in your garden.

As in past seasons we will be testing several varieties of new annuals this year and will have a few extra plants if any of you wish to try them. If you wish to get better acquainted with any of the varieties of plants growing in our nursery tell us about it, and we will be glad to write you a note or telephone you when they may be seen in blossom. Prospective customers are welcome to visit our nursery.

\section{NURSERY INSPECTION}

Our nursery is regularly inspected by an authorized inspector from the Minnesota State Department of Agriculture. Our Certificate of Inspection is on file at our nursery and may be seen by any one. These certificates are a protection to our customers. All plants apparently affected by injurious insects or diseases must be destroyed before the certificate is given.

\section{OUR AIMS}

To continually improve our service to you. To grow and handle all our plants so that thev will give you perfect satisfaction. To purchase all seeds and stocks from reliable sources so that our plants will be as represented and as near as possible true to name. We cannot always depend upon plants grown from seed to be true to color, etc. To get better acquainted with our customer's ideals about gardening.

To, if possible, make a satisfactory adjustment if for any reason a customer should feel that our plants are not what he ordered, or are not up to grade, or if any error should occur in filing your order, or the plants do not reach you in good condition. Our attention should be called to any unsatisfactory conditions within five days after receipt of goods.

\section{GUARANTEE}

While we guarantee all plants sent out by us to reach you in good condition and to be as represented, we find that due to many causes beyond our control we cannot guarantee the hardiness or growth of any plant sold by us and cannot be in any way held responsible for the crop nor for a sum greater than the original purchase price. All orders are received subject to shortage or conditions beyond our control.

\section{SUGGESTIONS FOR HANDLING PLANTS}

If sent by mail or express unwrap as soon as possible so as to reduce danger of heating. PLANT AT ONCE. Do not leave any kind of plant lying around in the wind, sun, or exposed places. If impossible to plant immediately put some moist soil around the roots, and place in a shady place out of the wind, but where it is not dark.

When planting, place the plants the same depth or only a little deeper than they were before. Do not bury any part of the leaves. Iress the soil firmly around roots', so firm that the plants cannot be pulled up easily. Water thoroughly, especially if the ground is dry. If the weather is hot and dry or there is a strong wind give the plants some protection. If impossible to protect the plants wait and do the planting in the evening.

\section{NOTES ON ORDERING}

Please write as plainly as possible.

Write only one item on a line.

Write your name very plainly.

Be sure to give your street and number.

Also the name of your Town and State.

Please give express office if different than postoffice.

\section{PRICES AND TERMS}

Our prices, with few exceptions, include postage or express charges provided the order amounts to one dollar or more. Payment should accompany all orders. We prefer that remittance be made by postoffice money order. 


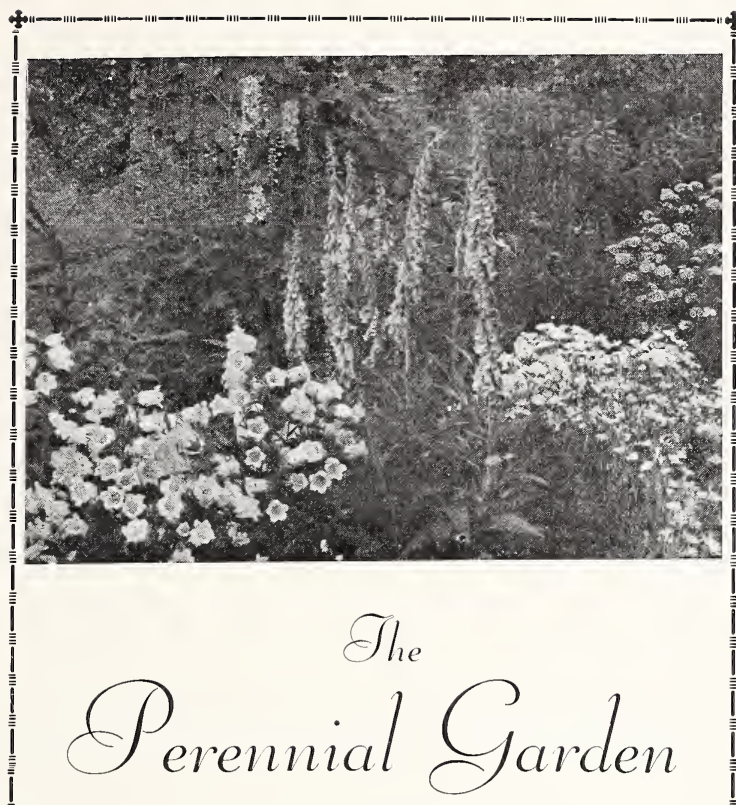

$C$ VERY GARDEN should be laid out with the idea of making a pretty picture. When the picture is built with hardy plants we are making for ourselves a picture that will have many pleasant surprises for us later on, for each day there is some new development. Beginning in April we may find some plant such as the Viola (often under the mulch) ready to expand into full bloom and gladden every heart with the message, "Spring is here." Then follows in quick succession the bright yellow Basket of Gold, Rock Cress, early Daisies, the graceful Columbine, the wonderful Peonises, the various blue Delphiniums, the yellow Coreopsis, and the beautiful Gaillardia, then the gorgeous Phlox. In September comes the dark blue Monkshood and Asters, and as the season closes we will find the Viola one of the last flowers to brave the cold weather.

For the most pleasing results it is generally necessary to use a few annuals among the perennials, to give our garden picture more color during the summer when there may be only a few perennials in bloom, and also to cover or hide some of the plants that become more or less unsightly as the season advances.

In laying out the garden avoid placing the plants in straight lines, as a better picture will result if the plants are placed in irregular shaped masses, always keeping the colors so they will harmonize.

Many people are under the false impression that once planted a perennial garden is finished, but a completed garden would be an impossibility to a garden enthusiast. One man in England has been fifteen years building his garden picture. All gardeners are constantly learning new things about plants and want to try some of the new varieties being introduced. It is a good idea to make written notes of plants seen in our friend's garden, especially if you think the plant would help make your own garden picture better.

For the perennial garden we should have good soil and moderately fertile. Thorough preparation of the soil is essential because perennials stay in the same place several years. Give good cultivation to conserve moisture and keep out the weeds.

With few exceptions perennials may bc planted at any time but those planted very late in the spring may not produce satisfactory results the first season.

While not always necessary winter protection in the form of coarse hay, straw, or corn stalks is beneficial, as it prevents alternate thawing and freezing, also heaving. Put the mulch on after the ground has frozen solid. 


\section{Perennial Plants}

\section{ACHILLEA (Yarrow)}

THE PEARL - 2 ft. ; all summer. An easily grown plant bearing graceful clusters of double white, daisy-like flowers on long stems. Suitable for cutting. It spreads rapidly and should be divided every year or two in order to keep the flowers large. Each 25 cents; 12 for $\$ 2.50$.

FILLIPENDULINA-Fern-ieaved or Yellow Yarrow. 3 feet summer. Flat heads of yellow flowers which may be dried for winter bouquets. Each 25 cents; 12 for $\$ 2.50$.

\section{ACONITUM (Monkshood)}

WILSONI-3 to 4 feet. Sept. A beautiful fall blooming plant, old plants producing several spikes of dark blue flowers, each flower resembling a monks hood. Leaves dark green and glossy. The roots are poisonous and should not be planted in or near the kitchen garden or a children's garden. The plant thrives in sunlight, but the flowers will last longer if in partial shade. Used in borders and masses for both the flowers and the leaves. Aconites do not reach full perfection the first year. Each 30 cents; 12 for $\$ 3$.

\section{AGROSTEMMA (Mullein Pink)}

CORONARIA ATROSANGUINEA-Sometimes called Dusty Miller or Rose of Heaven. 1 to 2 feet, June to Sept. Foliage silvery. Flowers blood red on long stiff stems. Each 25 cents; 12 for $\$ 2.50$.

\section{ALYSSUM}

SAXATILE COMPACTUM (Basket of Gold)-1 foot, early spring. One of the earliest flowering plants, suitable for borders or the rock garden, making a spreading mat of bloom. Flowers bright yellow, foliage a gray green. When ripe the seed pods have a lace-like appearance and may be used in winter bouquets.

ARGENTEUM (Madwort)-1 foot, all summer. Quite different from the above, having a small smooth green leaf, silvery beneath. Clusters of very small yellow flowers. For rockeries or the front of the border. Each 25 cents; 12 for $\$ 2.50$.

\section{ANCHUSA (Alkanet)}

ITALICA, DROPMORE VARIETY - 3 to 5 feet, June to Sept. A somewhat coarse, free blooming plant. Flowers a beautiful gentian blue, forming a loose panicle. Foliage grayish, rough and shiny. Succeeds best in partial shade. Keep the dead blossoms removed. Each 25 cents; 12 for $\$ 2.50$

MYOSOTIDIFLORA-1 foot, May. A dwarf form of anchusa from Russia with clusters of blue flowers resembling forgetme-nots. Suitable for the rockery. Each 35 cents; 12 for $\$ 3.50$.

\section{ANTHEMIS (Marguerite)}

KELWAYI -2 feet, all summer. Beautiful finely cut dark green foliage with yellow daisy-like flowers. Will grow in poor soil. Each 25 cents; 12 for $\$ 2.50$.

\section{AQUILEGIA (Columbine)}

The columbines are often miscalled honeysuckle. They grow from two to three feet high and produce an abundance of graceful, long-stemmed flowers for the late spring and early summer months. After the blooming period the foliage remains graceful and attractive. Columbines are not particular about the soil but seem to prefer a well drained sandy loam. They will grow in partial shade. Our plants are two year old clumps.

CHRYSANTHA-Golden yellow.

CHRYSANTHA ALBA - A white variety

COERULEA (Rocky Mountain Columbine)-Blue and white. LONG SPURRED_Fink and rose shades.

MRS. SCOTT ELLIOT'S HYBRIDS-Mixed colors.

DOBBIE'S HYBRIDS-Mixed colors.

ROSE QUEEN-Rose shades.

GRANDULOSA-Black violet with white corolla.

Each 40 cents; 12 for $\$ 4$. 


\section{ARABIS (Rock Cress)}

ALPINA-6 to 8 inches, early spring. A very desirable early blooming rock garden plant with a grayish foliage and an abundance of white flowers. The foliage remains good all summer. It is also suitable for the front of the hardy border. Large plants. Each 40 cents.

\section{ARENARIA (Sandwort)}

MONTANA-6 inches, May. Close tufts of leaves covered with small silvery white flowers. An alpine plant suitable for the rockery or edging. Each 25 cents; 12 for $\$ 2.50$.

\section{ASTERS}

A few hardy asters should be planted in every border to supply bloom during the fall months. All are suitable as cut flowers during the cay, but the flowers of many varieties tend to close up during the evening.

ST. EGWIN-2 to 3 feet, Sept. A dwarf variety with bright, shiny, deep green fine foliage, being almost completely covered with dull pink flowers. A beautiful plant. Award of Merit, Royal Horticultural Society.

HAUSERI -4 feet, Sept. A tall branching variety. Deep pink flowers.

CLIMAX - 5 feet. One of the best and showiest of fall asters. Pyramidal spikes of large light lavender blue flowers. One of the best asters to use as a cut flower.

Any aster, Each 30 cents; 12 for $\$ 3$

\section{BOLTONIA (False Chamomile)}

AUSTRALIS - 2 to 4 feet, June. A strong growing bushy plant. Foliage dark green in shape similar to the leaves of peas. Racemes of indigo blue flowers. Will grow in any soil and prefers full exposure to the sun. Clumps each 50 cents.

\section{BELLIS (English Daisy)}

See under Annuals.

\section{BOLTONIA (False Chamomile)}

The Boltonias are tall leafy plants, furnishing an abundance of bloom for the late summer and autumn. Plant in rather large groups. Should be divided about every three years if large blooms are desired. An excellent plant for the hardy border. Suitable for cutting.

ASTEROIDES - 5 to 6 feet. White. Each 25 cents. 12 for $\$ 2.50$.

LATISQUAMA 4 to 5 feet. Pink. Each 25 cents; 12 for $\$ 2.50$; Clumps 50 cents each.

\section{CAMIPANULA (Bellflower)}

CARPATICA (Harebell) -9 inches, July to Oct. A favorite bellflower for edges and the rockery. The plants are dwarf and compact, bearing many graceful clear blue bell shaped flowers on slender stems. Only one flower to a stem. Clumps each 40 cents; 12 for $\$ 4$.

MEDIUM (Canterbury Bells)-1 to 2 feet, June-July. These well-known flowers are excellent for cutting. Laige well grown plants make a beautiful display in the garden. Pink or blue. Each 25 cents; 12 for $\$ 2.50$.

PERSICIFOLIA (Peach Bells) -2 to 3 feet, July-August. This is one of the best bell flowers and is much hardier than the canterbury bells. Each plant will produce a number of stems, each stem bearing many large dark blue flowers. An excellent cut flower. Keeps well. Clumps each 40 cents; 12 for $\$ 4$.

\section{CARNATION}

GRENADIN-12 to 18 inches, summer. Carnations are quite hardy if given some protection. The plants are similar to the garden pinks and produce many single and double flowers. Are fragrant, very good for cutting. Scarlet or white. Each $2 s$ cents; 12 fo $\$ 2.50$.

\section{CENTAUREA (Cornflower)}

The cornflowers are of easy culture, preferring an open sunny position but not particular as to soil. Very hardy. 
MONTANA 2 feet, June to Sept. Blue or white. Each 25 cents; 12 for $\$ 2.50$.

DEALBATA-2-3 feet, June-July, pink. Clumps each 40 cents; 12 for $\$ 4$.

MACROCEPHALA-3-4 feet, July to frost. with large yellow thistle-like flowers. A good cut flower. Each 25 cents; 12 for $\$ 2.50$. Clumps each 40 cents.

\section{CERASTIUM (Snow-in-Summer)}

TOMENTOSUM-4 to 8 inches, early summer. A very hardy low growing plant with silvery white foliage, producing large numbers of small white flowers. Suitable for carpeting dry sunny places, as a grave-covering. Also for mass effects in rockeries and as an edging plant. Each 25 cents; 12 for $\$ 2.50$.

\section{CHELONE}

See Pentstemon Torreyi.

\section{CHIVES}

A popular herb having a mild onion flavor. May also be used in the hardy border for its light purple ball shaped flowers in early summer. 18 inches. Each 25 cents; 12 for $\$ 2.50$.

\section{CHRYSANTHEMUM (Shasta Daisy)}

ALASKA (Shasta) DAISY - 2 feet, all summer. A beautiful large white daisy-like flower with yellow center. Each 25 cents; 12 for $\$ 2.50$; clumps each 40 cents.

EDWARD VII-Similar to the Alaska daisy but a little later. Clumps each 40 cents.

MARKET FAVORITE-Same as above but much longer stems. Each 30 cents.

HARTJE and ELDER DAISY (The Decoration Day Daisy)2 feet, May to July. A medium sized-daisy, coming into bloom about Decoration Day. The flowers have stiff stems and make excellent cut flowers, keeping a long time. We do not hesitate to recommend it. Very hardy. Each 30 cents; 12 for $\$ 2.50$.

\section{COREOPSIS}

LANCEOLATA GRANDIFLORA - 3 feet, all summer. Large bright yellow flowers on long stems. An excellent cut flower if handled carefully after cutting. Each 25 cents; 12 for $\$ 2.50$.

\section{DELPHINIUM}

DELPHINIUM-2 to 7 feet, June to fall. Often called the Queen of summer flowers. They are very hardy and may be used as the predominating flower in the border or as single specimens. I hey will grow in any kind of soil provided it is rich and in good condition. A succession of flowers will be produced if none are allowed to go to seed. There is a great variety of color, ranging from the palest blue to a violet blue with many intermediate shades, some being blended with pink and lavender.

\section{ENGLISH HYBRIDS}

WREXHAM (Tall)-Clumps. Each 50 cents.

BLACKMORE \& LANGDON (Tall)-Clumps. Each 50 cents. SUTTON'S HYBIRDS (Tall)-Clumps. Each 40 cents.

KELWAY'S HYBRIDS (Tall)-Clumps. Each 40 cents.

EXCELSIOR STRAIN (Tall)-1 year. Each 25 cents.

\section{OTHER VARIETIES}

VANDERBILT HYBRIDS (Tall)-Clumps. Each 50 cents.

BELLADONNA-3 to 4 feet. Light blue. Clumps. Each 35 cents.

BELLADONNA IMPROVED-Light blue. Clumps. 'Each 40 cents.

BELLAMOSSUM-Dark blue. Clumps. Each 35 cents.

GOLD MEDAL HYBRIDS-Clumps. Each 40 cents.

SUTTON'S QUEEN OF THE BLUES-Dwarf. Clumps. Each 40 cents.

CHINESE- 1 to 2 feet. Dark blue or white. Clumps. Each 35 cents.

BUTTERFLY 1 to 2 feet. Dark blue, lavender, white. Clumps. Each 35 cents.

SUMMER CLOUD-5 feet. White. Each 50 cents. FOR PRICE OF 12 MULTIPLY PRICE OF SINGLE PLANT BY 10. 
BABY PLANTS OF WREXHAM DELPHINIUM, small plants started about March 1, transplanted once. Most of these will bloom in August or September. Ready about May 20. SIX FOR $\$ 1.00$.

\section{DIANTHUS (Pinks)}

No hardy garden would seem complete without a few of the sweet scented hardy pinks. They may be used in any type of hardy garden, and when not in bloom their foliage helps to relieve the general green color prevailing. They prefer a warm soil free from excessive moisture.

SEMPERFLORENS-1 foot; all summer. Mixed colors.

PLUMARIUS-Double flowers, mixed colors.

CYCLOPS -1 foot, clove scented, pink.

CAESIUS (Cliff Pink) -1 foot, delicate rose color.

DELTOIDED (Maiden Fink) - 5 inches. Leaves very fine, dark green. Flowers pink.

DOUBLE ROSE PINK--A selected pink bearing fragrant rose pink double flowers. Very fine.

\section{DOUBLE WHITE.}

ALL PINKS, EACH 25 CENTS, 12 FOR \$2.50.

\section{DICENTRA (Bleeding Heart)}

SPECTABILIS - 2 fcet. Early spring. An attractive hardy plant, bringing to many of us choice memories of our childhood days. The p'ant has a much cut foliage and bears long racemes of graceful pink and white heart-shaped flowers. It is easily cuitivated and will grow either in full sun or partial shade. Each 50 cents.

EXINIAE (Plumy Bleeding Heart)-Foliage muc's more finely cut than in the common Bleeding Heart. It continues to blossom all summe: Each 35 cents.

\section{DIGITALIS (Foxglove)}

GLOXINIAEFLORA-2 feet; June-July. Stately old garden favorites. Used in gardens, shrubbery borders and for naturalizing. Mixed colors. Each $\angle 5$ cents.

\section{ECHINOPS (Globe Thistle)}

RITRO-3 to 4 feet; all suinmer; an interesting, rather coarse plant, especially suited for naturalizing in wild gardens and sh ubberies. Leaves deeply cut, silvery white beneath. The metallic blue ball-like flowers are borne on long silvery white stems, and may be dried and kept for a long time. Clumps. Each 40 cents.

\section{EUPHORBIA (Milkwort)}

POLYCHROMA-1 to 2 feet; April-May. Like Echi-ops the Euphorbia are an interesting group of plants. Our Christmas Poinsettias belong in this group. We do not grow them for their flowers but for the b:ight colored leaves at the top of the stems. During the blooming period the tip leaves of the Milkwort turn bright yellow. The plant forms a hemispherical clump, and is suitable for both formal and informal gardens. Clumps. Each 40 cents.

\section{GAILLARDIA (Blanket Flower)}

GRANDIFLORA - 2 feet; all summer. The Gaillardia is one of the most satisfactory garden plants as it gives a great profusion of bloom over a long period. The large flowers in various combinations of red and yellow are excellent for cutting and will keep well. Each 25 cents; 12 for \$2.50.

STANDHOLDER-Stiffer stems than the above. Clumps. Each 40 cents.

\section{GYSOPHILA (Baky's Breath)}

PANICULATA-2-3 feet. July. The small white flowers are useful in giving a mist-like effect in the mixed border and in bouquets. Every garden for cut flowers should have a good suppy of Baby's Breath. The flowers may be dried and kept for use at any time of the year. Each 25 cents; 12 for $\$ 2.00$.

BRISTOL FAIRY - 2 feet; a double flowered variety which blooms most of the season. Grafted plants from 3 inch pots. Each 50 cents.

REPENS-July-August. A beautiful trailing variety for the rockery. Each 25 cents; 12 for $\$ 2.50$. 


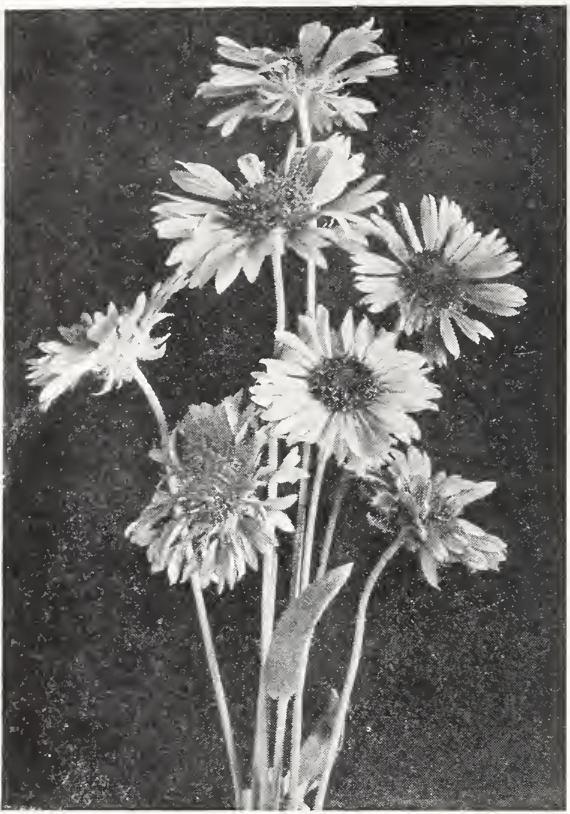

Gaillardia Grandiflora

\section{HELENIUM (Sneezewor:)}

RIVERTON GEM-3 to 4 feet. August-October. Heleniums are allied to the sunflowers and produce in autumn masses of daisy-like flowers. The flowers of Riverton Gem are old gold with splashes of darker shades, later turning to a wallflower red. Clumps. Each 40 cents.

\section{HELIOPSIS (Hardy Zinnia)}

PITCHERIANA -2 to 3 feet; July-August. Similar to small sunflowers. Flowers golden yellow, about 2 inches in diameter. Excellent for cutting. Each 25 cents; 12 for $\$ 2.50$.

\section{HEMEROCALLIS (Day Lily)}

FULVA--3 feet; July. The easily grown day lilies should be found in every border of hardy plants. Foliage tall and grasslike. Flowe:s coppery orange. Each 25 cents; 12 for $\$ 2.50$.

\section{HEUCHERA (Coral Bells)}

SANGUINEA - 12 to 18 inches; June to Sept. A good plant for the front of the border. Bright crimson flowers on slender stems. A fine cut flower. Each $\mathbf{5 0}$ cents.

\section{HIBISCUS (Mallow)}

The mallows prefer a moist soil. The showy hollyhock-like flowers appear in August and September. Very often the lower part of the root shows signs of decay in the early spring, but if the crown is sound the plant will grow. Starts growth very late. Height 3 to 6 feet.

CRIMSON EYE-Flowers white or pink with dark center. GIANT MALLOWS-Red, white, or pink.

EACH 20 CENTS; 12 FOR $\$ 2.00$.

\section{HOLLYHOCKS}

SINGLE-Red, pink or mixed colors.

DCUBLE FLOWERED-Newport Pink ; Yellow ; Rose; Aypleblossom; Red.

EACH 25 CENTS; 12 FOR $\$ 2.50$.

\section{IBERIS (Candytuft)}

GIBRALTARICA-6 to 10 inches, An evergreen plant covered with masses of pinkish-white blossoms in early summer. Suitable for rockeries and edges. Each 25 cents; 12 for $\$ 2.50$. 


\section{IRIS}

SIBERIAN-2 to 3 feet. Rich blue. Each 25 cents.

MIXED VARIETIES - 2 to 4 feet, mostly shades of blue. Each 25 cents; 12 for $\$ 2.50$.

\section{LIATRIS (Blazing Star)}

PYCNOSTACHYA-4 to 5 feet. Late summer. A bold plant for the border, with its tall slender spikes of rich rosy purple flowers. Plant in masses for the best effects. Flowers may be dried. Clumps. Each 40 cents; 12 for $\$ 4.00$.

\section{LINUM (Flax)}

PERENNE -2 to 3 feet, all summer. Bush-like plants, producing daily an abundance of blue blossoms. As a rule the blossoms close about noon. The plants prefer an open, warm place. Each 25 cents; 12 for $\$ 2.50$. Clumps each 40 cents.

\section{LUPINUS (Lupines)}

ATROCOERULEUS (Blue)-3 feet. Early summer. The Lupines are desirable garden plants producing beautiful spikes, a foot long, of pea-shaped flowers. They are perfectly hardy and make an excellent cut flower.

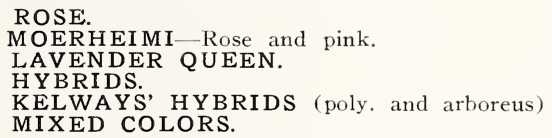

CHALCEDONICA 4 feet; June to August. A very hardy old fashioned flower, bearing flat clusters of brick red flowers during the summer.

CHALCEDONICA ALBA-A white form of the above.

HAAGENANA

ARKWRIGHTII $\}$ Dwarf forms about 1 foot high.

ALPINE - 6 inches. A dwarf form with rose-pink flowers, suitable for the rockery.

CLUMPS. EACH 40 CENTS; 12 FOR $\$ 4.00$.

\section{LYTHRUM (Loosestrife)}

ROSEUM SUPERBUM-4 feet; July-August. Very showy plants blooming at a period when there may be a scarcity of flowers in the hardy border. Blossoms rosy lilac on long stems. Each 25 cents; 12 for $\$ 2.50$. Clumps. Each 40 cents.

\section{LYTHUS (Everlasting Sweet Pea)}

LATIFOLIUS - Climbers, 6 feet; all summer. Suitable for covering trellis, arbors, etc. Mixed colors. Each 25 cents; 12 for $\$ 2.50$. 2-year-o'd plants each 40 cents.

\section{MYOSOTIS (Forget-Me-Nots)}

Nearly every one is familiar with the charming bright blue flowers of the Forget-Me-Nots. They are suitable for the border or rock garden and as a ground cover for tulip beds. They prefer partial shade and plenty of moisture. Height 6 inches.

Each 25 cents; 12 for $\$ 2.50$.

\section{PAPAVER (Poppy)}

NUDICAULE (Iceland Poppy)-1 foot, all summer. A short lived perennial, having cup-shaped flowers on long slender stems. The graceful flowers arise from a neat tuft of finely cut leaves. The bright colors of the flowers and their long keeping qualities after being cut make the Iceland Poppy a desirable plant for any garden. Orange or yellow. Each 25 cents; 12 for $\$ 2.50$.

DOUBLE FLOWERED-Mixed colors. Each 25 cents.

GIBBSON'S GIANT-Orange. Clumps. Each 35 cents.

ORIENTALE (Oriental Poppy) - -3 feet; June-July. Scarlet. Each 25 cents; 12 for $\$ 2.50$.

\section{PHLOX}

Every border should have masses of Phlox to give it a bright color in late summer. For the best results Phlox should have a deep soil and plenty of moisture at flowering time.

ELIZABETH CAMPBELL-Salmon, medium height. Each 35 cents; 12 for $\$ 3.50$. 
LOTHAIR-4-5 feet. Lavender

MISS LINGARD-4-5 feet. Early white, lavender eye.

MRS. JENKINS-2-3 feet. Late white.

RHEINLANDER-Soft pink.

R. P. STRUTHERS-3-5 feet. Carmine.

SIEBOLD - Orange scarlet.

Except where noted, EACH 25 CENTS; 12 FOR $\$ 2.50$.

\section{BABY PHLOX}

These are young plants started from root cuttings during the winter. If given good care they will bloom the first year. We offer the following varieties:

ELIZABETH CAMPBELL; DEUTCHLAND (Scarlet);

FIREBRAND (Bright Red). Each 20 cents; 12 for $\$ 2.00$. RHEINLANDER; R. P. STRUTHERS; SIEBOLD. Each 15 cents; 12 for $\$ 1.50$.

\section{PHLOX SUBULATA (Creeping Phlox)}

Dwarf plants about 3 inches high, covered in June with a mass of bright flowers. Valuable for the rockery, as a ground cover for graves. Rose, white or lilac. Each 25 cents; 12 for $\$ 2.50$.

\section{PENTSTEMON (Bearded Tongue)}

PUBESCENS - 1 to 2 feet; June. A very satisfactory plant for the border, growing in almost any location, also suitable for the rockery. Many pale lavender flowers on long spikes. Clumps. Each 30 cents; 12 for $\$ 3.00$.

BARBATUS TORREYI -3 to 4 feet; all summer. The plant consists of a low bunch of dark green leaves from which arises tall spikes of bright scarlet flowers. Suitable for cutting. Each 25 cents; 12 for $\$ 2.50$; Clumps, each 40 cents.

UNILATERALIS -24 to 30 inches. A June flowering variety producing 6 to 10 erect spikes of opalescent blue flowers. A splendid cut flower. Each 40 cents.

\section{PHYSALIS (Chinese Lantern)}

FRANCHETTI - 1 to 2 feet. A plant belonging to the same family as the ground cherry; grown for its bright red seed pods which are extensively used for decorating. Generally needs spraying with an arsenical poison in order to have perfect puds. Each 25 cents; 12 for $\$ 2.50$.

\section{PHYSOSTEGIA (False Dragon Head)}

VIRGINICA-3 to 4 feet; July-August. Forms dense bushes with delicate pink tubular flowers similar to a tiny snapdragon blossom. Clumps. Each 40 cents.

\section{PLATYCODON (Balloon Flower)}

GRANDIFLORA - 1 to 2 feet; June-Sept. Large blue or white bell-shaped flowers. Should be planted on a well drained soil. Siarts growth very late. Clumps. Each 40 cents; 12 for \$4.

\section{PYRETHRUIM (Daisy)}

ROSEUM (Painted Daisy) - 2 feet; spring and fall. A beautiful plant with fernlike leaves. Daisylike flowers ranging from white to red. Suitable for cutting. Each 25 cents; 12 for $\$ 2.50$. Clumps. Each 40 cents.

KELWAYS-Mostly red. Each 25 cents. Clumps, Each 40 cents.

ATROSANGUINEUM - Red. Each 30 cents.

ULIGINOSUM (Giant Daisy) - 3 to 5 feet; fall. Tall plants suitable for the back of the border. Flowers medium sized white daisies. Each 25 cents. Clumps. Each 40 cents.

\section{RIBBON GRASS}

Leaves green with white stripes. Flowers useful for drying. Each 25 cents.

\section{RUDBECKIA (Cone Flower)}

PURPUREA GRANDIFLORA (F'urple Cone Flower)-4 feet Scpt.-Oct. A plant suitable for growing among shrubs or at the back of a border. The crimson-purple flowers with drooping petals and large dark conelike centers are similar to the smaller varieties of sunflowers. Each 25 cents; 12 for \$2.50.

FULGIDA-2 feet; a yellow. flowered coneflower. Each 25 cents

GOLDEN GLOW-6 feet; August. Large yellow double flowers. Each 25 cents; 12 for $\$ 2.50$. 


\section{SALVIA (Meadow Sage)}

AZUREA GRANDIFLORA - 4 feet; August-Sept. Very hardy. A rather coarse plant, but useful in the border for its spikes of light blue flowers. Each 25 cents.

\section{SAPONARIA}

OCYMOIDES SPLENDENS-6 inches; June-July. A very showy dwarf trailing plant with pink flowers, coming into bloom just after the creeping phlox. Fine for the rockery. Requires little care, spreads rapidly. Each 25 cents; 12 for $\$ 2.50$.

\section{SCABIOSA (Blue Bonnet)}

CAUCASICA -18 inches; June-Oct. A pretty border plant similar to the annual Scabiosa (pincushion plant). Lavender flowers on long stems, a good cut flower. Each 25 cents; 12 for $\$ 2.50$. Clumps. Each 40 cents.

\section{SEDUMS}

The dwarf Sedums are especially suited to the rockery and sunny places. They like sandy soil.

ACRE (Golden Moss)-Yellow star-shaped flowers in July. ALBUM-Similar to above, flowers white.

EWERSII-Blue gray foliage, dull rose colored flowers.

KAMSCHATICUM-Green foliage, yellow flowers.

SPURIUM-Rosy crimson flowers, July-August.

ANY OF ABOVE, EACH 25 CENTS; 12 FOR $\$ 2.50$.

SPECTABILE-Tall, 18 inches; light green foliage. Rose colored flowers in the fall. Clumps. Each 40 cents.

\section{STATICE}

LATIFOLIA - 2 feet; summer. The leathery leaves form a tuft at the ground from which arises several stiff stems bearing numerous small lavender flowers similar to Baby's Breath. Give full sunlight. Flowers may be dried and kept a long time. Each 25 cents; 12 for $\$ 2.50$.

\section{SWEET WILLIAM}

\section{MIXED COLORS.}

PINK BEAUTY.

SCARLET BEAUTY.

EACH 25 CENTS; 12 FOR $\$ 2.50$.

\section{THALICTRUM (Meadow Rue)}

ADIANTIFOLIUM-3 to 4 feet; June. A graceful plant having a foliage similar to Maiden Hair Fern. Plumes of small cream colored flowers. Each 30 cents. Clumps. Each 60 cents.

AQUILEGIFOLIUM-4 feet. Graceful foliage similar to that of the Columbine. Rosy purple flowers. Each 30 cents.

GLAUCUM-3 to 4 feet. July. Leaves blue-grey. Flowers yellow and fragrant. Clumps. Each 40 cents.

\section{VERONICA}

SPICATA -2 feet; July-Aug. The speedwells with their long spices of violet-blue tlowers are very showy in the sunny herbaceous border. Clumps. Each 40 cents.

\section{VIOLA}

The Violas which are similar to pansies are becoming more popular each year. They are suitable for rockeries, edges and mass bedding. Will grow in full sun or partial shade. They bloom from early spring until heavy frost in the fall.

JERSEY GEM-6 inches. One of the hardiest violas. Flowers bright purple.

APRICOT-6 inches. Flowers a rich apricot color, specially selected from plants true to color.

EITHER VARIETY; EACH 25 CENTS; 12 FOR $\$ 2.50$.

For other. varieties of Violas see Annual Flower List, page 16.

\section{YUCCA (Adam's Needle)}

FILAMENTOSA-6 feet; June-July. An effective plant for isolated places and on dry banks where few other plants will thrive. May be used in the rockery. Leaves swordlike. Flowers creamy white in large branching spikes. 2 year old plants. Each 30 cents. 

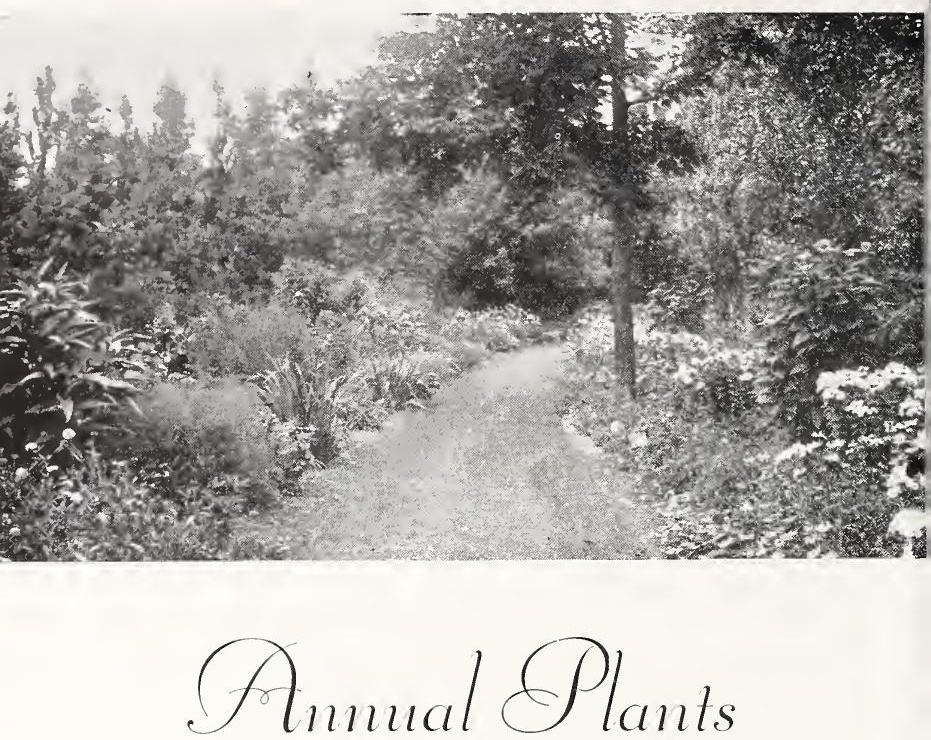

Unlike Perennials the Annual Flowering Plants complete their growth the first season. An annual plant will generally produce more blossoms than a hardy one, in a single season. On this account, as well as the lower cost per plant, annual plants are especially desirable when planting a place that is rented for a short period. If there is no shrubbery around the home very attractive pictures may be made by the use of Annuals. They will also be effective in tying the house to the ground. Annuals may be used in either formal or informal gardens, care being taken to have the colors harmonize.

Annuals should also be used in the hardy border to give color at those times when there a:e likely to be few Perennials in blossom, and also to hide those that become unsightly as the season advances.

\section{THE CUT FLOWER GARDEN}

If the Annuals are bei.ng grown for cut flowers only, they should be planted in rows about two feet apart and each plant given plenty of room, good cultivation and plenty of moisture. Large flowers cannot be produced in a crowded and neglected garden. It is often desirable to remove all side flower buds if especially fine flowers are wanted, but this reduces the number of blossoms.

A cut flower garden is generally placed at the rear of the yard and slould if possible be separated from the rest of the yard by some shrubs, as a cutting garden cannot always be in a show condition.

\section{ANNUAL PLANTS FLAT GROWN}

Unless specified otherwise all our Annual Plants are grown in flats (shallow boxes) and have been once transplanted. They have a good root system and if properly handled (see page 2) will give satisfaction and there should be no loss. As these are sold at a much lower price, due to less labor in producing and caring for them people should not expect to get quite as quick results as is possible with the higher priced potted plants.

When selecting flat grown plants avoid the tall lanky plants, and choose the stocky ones as they will give much better results and with less care.

\section{AGERATUM}

A very useful plant for bedding, edging or window boxes. Flowers light blue, do not fade, and are not spoiled by rain.

FRASERI-12 to 18 inches. Makes a large plant. In pots only. Each 25 cents. Expressage extra.

COPE'S PET -9 inches. Suitable for borders and general bedding.

LITTLE BLUE STAR-4 to 5 inches.

SIX FOR 15 CENTS; 12 FOR 25 CENTS; 100 FOR $\$ 1.65$. 


\section{ALYSSUM}

Sweet Alyssum is a dwarf growing plant covering the ground with a carpet of very small flowers. An excellent plant for edging. If some of the seed pods are removed the plant will continue to bloom until very late in the fall.

LITTLE GEM-White. 6 for 15 cents; 12 for 25 cents; 100 tor $\$ 1.65$. Plants in small pots each 5 cents.

LILAC QUEEN-Lavender flowers. 6 for 15 cents.

\section{ANTIRRHINUM (Snapdragon)}

Snapdragons have become very popular the past few years. They are excellent plants for bedding and for cutting. The Tom Thumb varieties may be effectively used in window boxes. SUTTON'S GOLDEN CHAMOIS (Tall) -A beautiful combination of soft pink and yellow.

SUTTCN'S RICH APRICOT (Intermediate)-Pink flowers with orange and yellow lips.

SUTTON'S BRIGHT PINK (Intermediate)-Rose pink.

GOLD QUEEN (Intermediate)-Yell $s$.

PURITY (Intermediate)—White.

ALL ABOVE VARIETIES, 6 FOR 20 CENTS; 12 FOR 30 CENTS; 100 FOR $\$ 2.00$.

MIXED COLORS (Intermediate)-12 for 25 cents; 100 for $\$ 1.75$.

\section{ASTERS}

Everybody admi es Asters. They make a fine display when grown in masses and are one of our best flowers for cutting. ROYAL ASTERS-Lavender; shell pink.

OSTRICH FEATHER ASTERS-Lavender; bright rose; salmon pink; violet blue.

BALL'S WHITE ASTER.

SUNSHINE OR ANEMONE FLOWERED ASTERS. A single aster. Mixed colors.

ANY OF THE ABOVE, 12 FOR 30 CENTS; 100 FOR $\$ 2$.

AMERICAN BRANCHING ASTERS-Mixed colors. 6 for 15 cents; 12 for 25 cents; 100 for $\$ 1.75$.

\section{BELLIS (English Daisy)}

The English Daisy is a perennial but we prefer to grow it as an annual. It is a low growing plant bearing many small double flowers. It prefers a cool location. Pink only. 6 for 20 cents; 12 for 35 cents.

\section{CALENDULA}

Calendulas or Pot Marigolds are free blooming plants growing readily in any good garden soil. We have selected what we beineve to be the best varieties for the use of our customers. In order to get large flowers for cutting Calendulas should have plenty of moisture and the side buds should be removed.

BALL'S ORANGE-Double, a rich orange color.

BALL'S GOLD-Double, a beautiful soft shade of yellow.

BALL'S SUPREME - Single, orange with brown center.

6 FOR 15 CENTS; 12 FOR 30 CENTS; 100 FOR \$1.75.

\section{CANNAS}

Red or green foliage. Potted plants. Each 25 cents. Expressage extra.

\section{CENTAUREA}

CYANUS - Bachelor Button. Double blue.

IMPERALIS-Sweet Sultan, mixed colors.

6 FOR 15 CENTS; 12 FOR 25 CENTS.

\section{COLEUS}

The Coleus is grown for its colored foliage. Suitable for window boxes. vases and bedding. Mixed varieties in small pots. Each 10 cents.

\section{COSMOS}

A late summer and fall blooming plant. Foliage fern-like. Flowers suitable for cutting. An excellent plant to use as a background for other plants or to hide unsightly fences. If possible use poor soil. Height 4 feet. 
HARBINGER STRAIN-A superior class of Cosmos. Flowers large, in soft shades of pink. peach, lavender, white and other intermediate shades. 6 for 15 cents; 12 for 30 cents; 100 for $\$ 1.75$

\section{CYNOGLOSSUM (Chinese Forget-Me-Not)}

An annual from China, growing from 18 to 24 inches high and producing through the summer sprays of intense blue Forget-MeNot-like flowers, sweet scented. 6 for 15 cents; 12 for 25 cents.

\section{DIDISCUS (Blue Lace Flower)}

A charming annual with dainty lavender-blue flowers. 18 to 24 inches high. Suitable for cutting. 6 for 15 cents; 12 for 25 cents.

\section{DIMORPHOTHICA AURANTIACA}

An exceedingly showy annual daisy from South Africa, 12 to 15 inches high. Flowers a glossy orange gold with dark center. A dry sunny position preferred. 6 for 15 cents; 12 for 25 cents.

\section{GERANIUMS}

Red, salmon, rose, white. In pots only. 25 to 35 cents each. Expressage extra.

\section{HELIOTROPE}

Sweet scented; grown from cuttings. Potted plants only. Small plants each 15 cents; 12 for $\$ 1.50$. Large plants each 25 cents. Expressage extra.

\section{HOLLYHOCKS (Annual)}

Some years, many people have been very much disappointed when spring arrived and they found that their hardy Hollyhocks had winter-killed. We have tested and found the annual Hollyhocks satisfactory. Pot grown plants, each 10 cents; 12 for $\$ 1$. Expressage extra.

\section{LARKSPUR}

The stock flowered Larkspur is an excellent outdoor plant, producing many long stemmed graceful flowers. Height about 3 feet.

Newport Pink; Lilac; Improved Exquisite (pink); Dark Blue. Any color, 6 for 15 cents; 12 for 30 cents.

\section{LOBELIA}

These charming little plants grow only a few inches high, and are covered with flowers the entire season. Suitable for ribbon bedding, edging, general bedding and window boxes.

BEDDING QUEEN-Deep purplish violet.

SAPPHIRE-A trailing variety, deep blue flowers with a white eye.

6 FOR 15 CENTS; 12 FOR 25 CENTS; 100 FOR $\$ 1.75$.

\section{MARIGOLDS}

The Marigolds, with their stately bright yellow flowers are old time favorites, and many people feel that their gardens are not complete without a few of them. They do best in a sunny location. The African varieties are tall, sometimes reaching a height of 5 feet. The French are dwarf, about 1 foot.

AFRICAN-Double orange; Double Lemon Queen.

FRENCH-Double-Gold Striped.

6 FOR 15 CENTS; 12 FOR 25 CENTS.

\section{NICOTIANA}

The Nicotiana is grown for its sweet fragrance when the flowers open late in the day. Flowers white. 6 for 15 cenis; 12 for 25 cents.

\section{PANSY}

The Pansy is a great favorite with most lovers of flowers. Its bright face appeals to personal feelings and is an inspiration to the gardener. Our Pansies are grown from one of the best strains of seed and we believe have always given satisfaction. All are twice transplanted and either in bloom or in bud. Mixed colors. Dozen 35 cents; 100 for $\$ 2.25$. 


\section{PETUNIA}

Very few plants will give the excellent results that can be obtained from Petunias when used in masses. They will grow in almost any kind of soil and will add considerable color to the garden.

Bedding Varieties:

ROSY MORN-Pink with white throat.

SNOWBALL-White.

BLUE BIRD-Dark blue.

MIXED COLORS.

12 FOR 25 CENTS; 100 FOR \$1.75.

Balcony Petunias-for Window Boxes:

DARK BLUE OR WHITE.

6 for 15 cents; 12 for 25 cents; 100 for $\$ 1.75$.

Large Flowering Varieties:

ELKS PRIDE-Rich velvety purple.

WHITE BEAUTY-White.

PURPLE PRINCE-Purple violet. (Large flowered)

6 FOR 15 CENTS; 12 FOR 30 CENTS; 100 FOR \$2.00. POTTED PLANTS EACH 15 CENTS; 12 FOR \$1.50.

DOUBLE ROSY MORN. Potted. Each 15 cents; 12 for $\$ 1.50$.

Express extra on potted Petunias.

\section{PHLOX DRUMMONDI}

Like Petunias the annual Phlox makes a fine bedding plant when used in masses. Each plant bears many blossoms. Also suitable for edges.

\section{CHAMOIS ROSE. VIOLET. \\ ISABELLINA-Pale yellow. SOFT LILAC. \\ ROSEA-Rose...}

ANY COLOR, 6 FOR 15 CENTS; 12 FOR 30 CENTS; 100 FOR $\$ 1.75$.

\section{SALPIGLOSSIS}

An attractive annual with tube-shaped flowers much like a Petunia but generally having several colors harmoniously combined in each flower.

SUTTON'S HYBRIDS -6 for 15 cents; 12 for 30 cents.

\section{SALVIA}

The Salvia with its bright red flowers appearing during the latter part of the summer, after many other flowers are past their prime, is always a welcome addition to any garden. Give it full sunlight. 6 for 15 cents; 12 for 30 cents.

\section{SCABIOSA (Pincushion flower)}

Tall, free flowering plants lasting until killed by frost. Blossoms keep well when cut. Mixed colors. 6 for 15 cents; 12 for 25 cents.

\section{STOCKS}

Cut and come again varieties, many double flowered.

PRINCESS ALICE-White.

LA FRANCE-Rose.

SAPPHIRE-Dark blue.

CREOLE-Creamy yellow.

MAY QUEEN-Delicate lilac.

6 FOR 15 CENTS; 12 FOR 30 CENTS.

BISMARK-Not as freely branching as the above. Many dou-

ble flowered. Mixed colors. 6 for 15 cents; 12 for 25 cents.

\section{VERBENA}

The Verbena is suited for beds, borders, or window boxes. Very free flowering, mixed colors. 6 for 15 cents; 12 for 25 cents.

\section{VINCA VINES}

Long trailing vines with green and white leaves. Used in window boxes and vases. Potted plants only. Each 25 cents; expressage extra. 


\section{VIOLAS}

Violas will bloom freely the first year from seed and may be used as annuals. All have been transplanted.

ADMIRATION-Large, dark blue.

APRICOT (Sutton's)-Rich apricot.

BLUE PERFECTION-Light blue.

BOSNIACA-Small reddish flowers.

FLORAIRE-Small blossoms of true blue. (Native of

Switzerland).

G. WERMIG-Rich violet blue.

LUTEA SPLENDENS-Bright yellow.

PALPILO -Blue and white.

PUCK-Clear violet and golden yellow.

ROSEA-Small rose colored flowers.

WHITE PERFECTION-White.

ANY VARIETY 3 FOR 15 CENTS; 6 FOR 25 CENTS;

12 FOR 40 CENTS; 100 FOR $\$ 2.25$.

\section{ZINNIA}

Giant Flowered Varieties in Separate Colors:

Apricot yellow; Cream; Flesh; Lemon; Rose; Salmon ; White; Miss Wilmott, soft rose pink. Any color, 6 for 15 cents;

12 for 30 cents.

Giant Flowered, mixed colors, 12 for 25 cents.

Lilliput or Pompon Zinnia:

Canary; Golden Orange; Salmon Rose; White. Any color, 6 for 15 cents; 12 for 30 cents.

Various Zinnias:

PICOTEE-Double, fringed flowers, mixed colors.

DAHLIA FLOWERED-Kelway's Rose Queen.

VICTORY-Double quilled flowers, colors mostly russet, orange, old rose and other autumn tints.

RED RIDING HOOD $\longrightarrow 12$ inches. Orange-red flowers, 2 inches in diameter. Fine for mass bedding.

ANY OF ABOVE, 6 FOR 15 CENTS; 12 FOR 30 CENTS.

\section{STRAWFLOW:ERS}

Cut when in bloom and hang upside down to dry in a cool, rather dark place.

HELICHRYSUM-The common daisy-like strawflower, mixed colors.

STATICE-Blue, yellow, rose.

6 FOR 15 CENTS; 12 FOR 25 CENTS.

\section{VEGETABLE PLANTS}

CABBAGE--Golden Acre-A very early round headed cabbage, Transplanted plants. 15 cents dozen.

CABBAGE-Copenhagen-Seedlings. 10 cents dozen.

CAULIFLOWER - Early Snowball - Transplanted. 20 cents dozen.

EGG PLANT-Transplanted. 25 cents dozen.

TOMATOES-Marglobe, Earliana, John Baer-Transplanted. 25 cents dozen.

PEPPERS - Sweet-Transplanted. 20 cents dozen.

Postage on Vegetable Plants Extra.

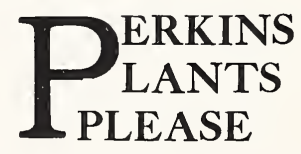



